Chirurgia (2021) 116: 737-747

No. 6, November - December

Copyright@ Celsius

http://dx.doi.org/10.21614/chirurgia.116.6.737

\title{
Prognosis Evaluation for Patients with Abdominal Trauma Using Usual Biological Parameters
}

\author{
Daniel Ion ${ }^{1,2}$, Mircea Gherghinescu ${ }^{3}$, Octavian Andronic ${ }^{1,2^{*}}$, Cristina Veronica Andreescü ${ }^{2}$, Dan Nicolae Păduraru ${ }^{1,2}$, \\ Alexandra Bolocan ${ }^{1,2}$, Cristian Russu ${ }^{3}$, Sandu Aprodu ${ }^{3}$, Georgiana Mationi ${ }^{3}$, Cosmin Nicolescu ${ }^{3}$, Daniel Popa ${ }^{3}$ \\ ${ }^{1} 3^{\text {rd }}$ Department of General Surgery and Emergency, Emergency University Hospital Bucharest, Romania \\ ${ }^{2}$ Carol Davila University of Medicine and Pharmacy, Bucharest, Romania \\ ${ }^{3} 1^{\text {st }}$ Department of Surgery, Mures County Emergency Clinical Hospital, Tg. Mures, Romania
}

${ }^{*}$ Corresponding author:

Octavian Andronic, MD

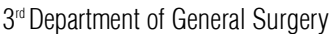

and Emergency

Emergency University Hospital

Bucharest, Romania

E-mail: octavian.andronic@umfcd.ro
Received: 07.11.2021

Accepted: 17.12.2021

\section{Rezumat}

Evaluarea prognosticului pacienților cu traumă abdominală utilizând parametri biologici uzuali

Introducere: Leziunile abdominale sunt responsabile pentru aproximativ $20 \%$ din toate decesele posttraumatice, dintre care $45^{-}$ $50 \%$ survin în primele 60 de minute. În prezent există mai multe scoruri de predicție pentru evolutia acestor pacienți, care țin cont de grade de leziune anatomică, semne clinice şi explorări imagistice şi paraclinice.

Scop:Scopul studiului a fost de a dezvolta un sistem de scor pentru a prezice mortalitatea la pacientii cu traumatisme abdominale prin utilizarea parametrilor biologici uzuali.

Metodă: A fost realizat un studiu multicentric retrospectiv, descriptiv, corelațional şi non-intervențional pe un eşantion de 157 de pacienți cu traumatisme abdominale, internați în perioada 2015-2021, în clinicile de Chirurgie Generală şi Urgență III al Spitalului Universitar de Urgență Bucureşti, respectiv în Clinica Chirurgie I a Spitalului Clinic Județean de Urgență Mureş. Au fost analizați următorii parametri biochimici: hemoglobină, hematocrit, număr de leucocite şi trombocite, coagulograma, glicemie, uree, creatinina, AST, ALT cu intentia de a verifica corelatia cu scorurile de mortalitate şi traumatisme ISS şi NISS. Pentru analiza statistică a datelor au fost utilizate aplicațiile Microsoft Excel şi MedCalc.

Rezultate: Eşantionul studiat a prezentat un raport de sex $\mathrm{M}: \mathrm{F}=$ 2,82:1, vârsta medie a fost de 47,45 $\pm 17,37$ ani. Elementele care 
au prezentat o corelație cu o valoare mai mare de 0,3 (şi p <0,01) au fost: vârsta, ALT, AST, ureea, hemoglobina, numărul de trombocite şi glicemia. Valorile limită pentru aceşti parametri în raport cu mortalitatea au fost stabilite prin analiza curbelor ROC. Acest fapt a permis conturarea unui scor predictiv care se corelează bine cu valoarea ISS şi NISS, curba ROC obținută utilizând ca parametri valoarea scorului de risc propus şi a mortalității evidențiind o bună putere predictivă a mortalității cu un AUC de 0,930 ( $\mathrm{p}<0,001)$.

Concluzii: Rezultatele studiului nostru au arătat că o serie de parametri biochimici pot contribui la modelarea unui scor cu valoare predictivă în ceea ce priveşte evoluția pacienților cu traumatisme abdominale.

Cuvinte cheie: traumă abdominală, ISS, NISS, AST, ALT, hematocrit, vârstă, glicemie, mortalitate

\begin{abstract}
Introduction: Abdominal injuries are responsible for approximately $20 \%$ of all post-traumatic deaths, $45-50 \%$ of which occurring in the first 60 minutes. Currently there are several prediction scores for the evolution of these patients, which take into account degrees of anatomical lesion, clinical signs and imaging and paraclinical explorations.

Aim: The aim of the study was to develop a scoring system to predict mortality in patients with abdominal trauma by using the usual biological parameters.

Method:A retrospective, descriptive, correlational and non-interventional multicenter study was performed on a sample of 157 patients with abdominal traumata, hospitalized between 20152021, in the General Surgery and the Emergency III clinics of the Emergency University Hospital Bucharest, respectively in the Surgery I Clinic of the Mures County Emergency Clinical Hospital. The following biochemical parameters were analyzed: hemoglobin, hematocrit, leukocyte and platelet counts, coagulogram, glycemia, urea, creatinine, AST, ALT with the intent to have the correlation with the ISS and NISS mortality and traumatic scores. Microsoft Excel and MedCalc applications were used for the statistical analysis of the data.

Results: The studied sample presented a sex ratio $\mathrm{M}: \mathrm{F}=2.82: 1$, the mean age was $47.45 \pm 17.37$ years. The elements that presented a correlation with a value greater than 0.3 (and $p<0.01$ ) were: age, ALT, AST, urea, hemoglobin, platelet count and glycemia. The cut-off values for these parameters in reference to mortality were established by analyzing the ROC curves. This fact allowed the outline of a predictive score that correlates well with the value of ISS and NISS, the obtained ROC curve using as parameters the value of the proposed risk score and mortality highlighting a good predictive power of the mortality with an AUC of $0.930(\mathrm{p}<0.001)$.

Conclusion: The results of our study showed that a number of biochemical parameters may contribute to shaping a score with predictive value in terms of the evolution of abdominal trauma patients.
\end{abstract}

Key words: abdominal trauma, ISS, NISS, AST, ALT, hematocrit, age, glycemia, mortality

\section{Introduction}

Trauma is associated with a high morbidity and mortality rate worldwide, having a significant socio-economic impact $(1,2)$.
According to the data provided by the WHO in 2000 approximately 5.8 million people died as a result of injuries. Currently, 14,000 deaths are recorded daily, and this number is expected to increase by $40 \%$ by 2030 (3). 
Deaths caused by trauma have a three-phase distribution, $45-50 \%$ of which occur in the first 60 minutes, $30-34 \%$ in the next 240 minutes and about $20 \%$ take place late in the ICU department $(3,4)$. About a quarter of the deaths occuring outside the "golden hour" time frame would be likely to be avoided by the timely administration of appropriate therapeutic methods (3).

Severe abdominal trauma accounts for about one fifth of all trauma deaths. As a result, a correct assessment and documentation of lesions must be completed as accurately and as quickly as possible, as they are crucial for the evolution of patients (5).

The maximum incidence of abdominal trauma is recorded in the active age groups (20-40 years), having an important impact on the workforce and, implicitly, on the economy (6).

Abdominal contusions are the most common, $13 \%$ of which are associated with lesions of the intra-abdominal organs, the spleen and liver being the most commonly affected (5,7-9). The omission or the inaccurate assessment of the intra-abdominal lesions may lead to an increase in late morbidity and mortality $(1,10)$. Mortality appears to be higher in patients with blunt abdominal trauma than in those with penetrating wounds (5).

For a better quantification of the effects of multivisceral traumata, a series of diagnostic algorithms have been proposed that take into account the assessment of the clinical signs and of the paraclinical and imaging investigations (10-12).

If the abdominal CT scan is considered the gold standard for the diagnosis of intraabdominal hemorrhagic lesions (sensitivity $92-97 \%$ and specificity $98.7 \%$ ), it reaches its limits in the case of the hemodynamically unstable patient, of the lesions evolving in two stages, for which the imaging signs appear after a free interval (hours-days) (12).

The trauma scores, although accurate in the anatomical description of the injury severity, need to be supplemented in terms of immediate post-traumatic pathophysiology; moreover, these scores depend on the best possible lesion documentation, most frequently obtained by imaging examinations.

As a result of these limitations, an attempt has been made to find biochemical scores as a predictor of the evolution and severity of the lesions (1,13-15). At present, although numerous studies have been conducted, there is no consensus on the predictive biochemical constants in regard to the abdominal traumata.

The aim of the study is to develop a scoring system to predict mortality in patients with abdominal trauma by using the usual biological parameters.

\section{Material and Method}

The present study is a retrospective one includes hospitalized patients between 20152021, and a multicentric one - includes hospitalized patients in the IIIrd General Emergency Surgery Clinic of the Emergency University Hospital Bucharest, respectively in the Surgery I Clinic of the Mures County Emergency Clinical Hospital. From a statistical perspective, the study is descriptive, correlational and non-interventional.

Patients with trauma with main abdominal injury, conservatively or surgically managed were included, and the patients with major lesions of other non-abdominal organs were excluded.

Microsoft Excel and MedCalc applications were used for the statistical analysis of the data.

The correlation between the variables was analyzed based on Pearson's correlation coefficient. This coefficient represent the linear relation between the variables, providing information on the correlation strength as well. Values above 0.3 were considered relevant in our study to further investigate that parameter. Significance was defined as a $\mathrm{p}$-value $<0.05$.

The efficiency of the model describing the connection between two variables was highlighted based on the constructed ROC (Receiver Operating Characteristics) curves. 


\section{Results}

The study sample was composed of 157 patients, out of which 41 women (representing 26.1\%) and 116 men (representing 73.9\%). The age of the patients included in the research varied between 17 and 89 years, with a mean value of $47.45 \pm 17.37$ years, with a maximum number of cases between 35 and 55 years.

From the perspective of the injuries associated with the traumatic event, the most common were the thoracic injuries (82 cases $52.56 \%$ ), followed by the splenic injuries (49 cases - $31.41 \%$ ), the liver injuries (47 cases $30.12 \%)$, respectively the craniocerebral injuries (46 cases - 29.48\%) (Fig. I).

The values of the biological parameters at the time of the hospital admission are presented in Table 1 (for normally distributed variables, data is shown as mean \pm SD and for the non-normally distributed variables, as median and range).

Based on the correlation matrix between all the clinical, biological and mortality parameters, the elements that showed a correlation with a value of the Pearson index $r>0.3$ ( $p<0.01)$ were highlighted: age, ALT, AST, urea, hemoglobin, platelets, respectively glycemia. To determine the cut-off for these parameters, we performed the ROC curve for their values and mortality (Table 2, Fig. 2-8).

Based on the cut-off determined by the ROC curves and the Youden index, we proposed a scoring system in which each parameter receives 0 or 1 point, the value of the score being given by the sum of the scores, the score having possible values from 0 to 7 (Table 3).

The distribution of the patients according to score value and discharge status, presented in Table 4 and Fig. 9 highlights the increase
Figure 1. Distribution of patients by associated injuries

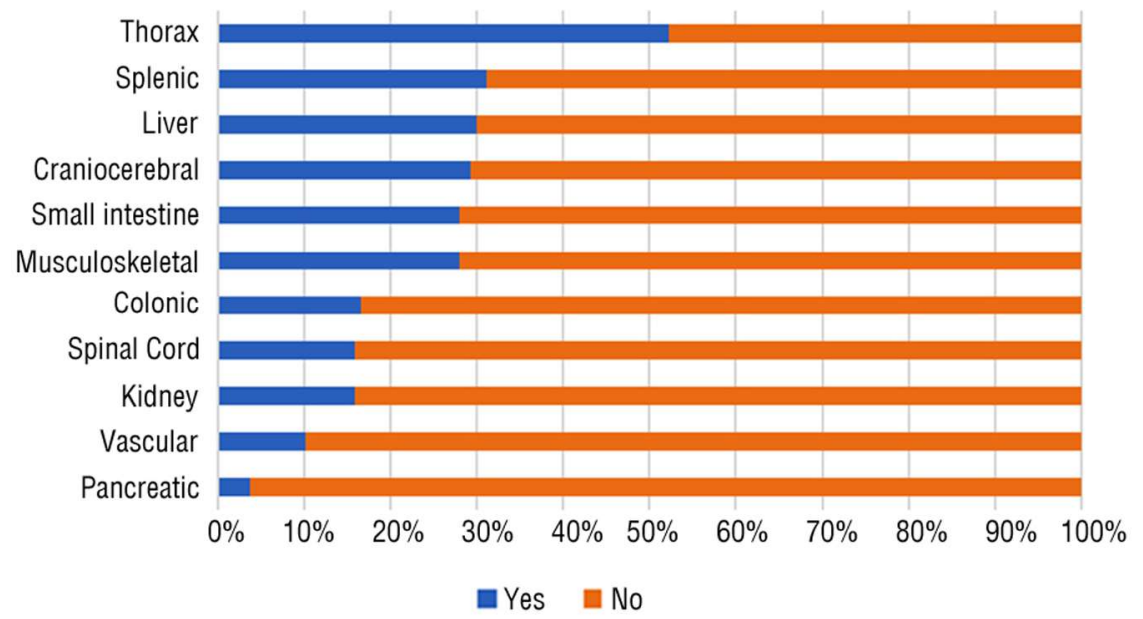

\begin{tabular}{|c|c|c|c|c|c|}
\hline Biological parameters & $\mathbf{N}$ & Mean & SD & Median & Range (min-max) \\
\hline ALT U/L & 147 & & & 59.300 & $5.200-327.600$ \\
\hline AST U/L & 146 & & & 48.000 & $10.000-625.000$ \\
\hline Creatinine $\mathrm{mg} / \mathrm{dL}$ & 147 & & & 0.860 & $0.460-90.000$ \\
\hline Glucose $\mathrm{mg} / \mathrm{dL}$ & 147 & & & 109.000 & $32.000-410.000$ \\
\hline Hematocrit \% & 154 & 34.970 & 7.6740 & & \\
\hline Hemoglobin $\mathrm{g} / \mathrm{dL}$ & 154 & 11.874 & 2.7198 & & \\
\hline INR & 134 & 1.164 & 0.2556 & & \\
\hline Leukocytes /10*3/uL & 154 & & & 13.400 & $2.700-31.400$ \\
\hline$\overline{\mathrm{PT}}$ & 147 & 13.485 & 3.0790 & & \\
\hline Platelets/10*3/uL & 154 & & & 214.000 & $25.000-881.000$ \\
\hline Urea mg/dL & 145 & & & 35.000 & $9.200-269.000$ \\
\hline
\end{tabular}


Table 2. Statistics related to the ROC curves for the researched parameters and mortaliy

\begin{tabular}{lccccc}
\hline & \multicolumn{2}{c}{ ROC } & & \multicolumn{2}{c}{ Youden index } \\
\hline & AUC & $\mathbf{p}$ & Cut off & Sensitivity & Specificity \\
\hline Age & 0.675 & 0.004 & $>49$ & 71.43 & 64.34 \\
\hline Glycemia & 0.693 & 0.009 & $>146$ & 60.00 & 86.07 \\
\hline ALT & 0.679 & 0.004 & $>77$ & 64.00 & 68.85 \\
\hline AST & 0.855 & $<0.001$ & $>54$ & 100.00 & 66.94 \\
\hline Urea & 0.689 & 0.007 & $>45$ & 56.00 & 79.17 \\
\hline Hb & 0.876 & $<0.001$ & $<9.6$ & 57.69 & 89.94 \\
\hline Platelets & 0.755 & $<0.001$ & $<155$ & 81.25 \\
\hline
\end{tabular}

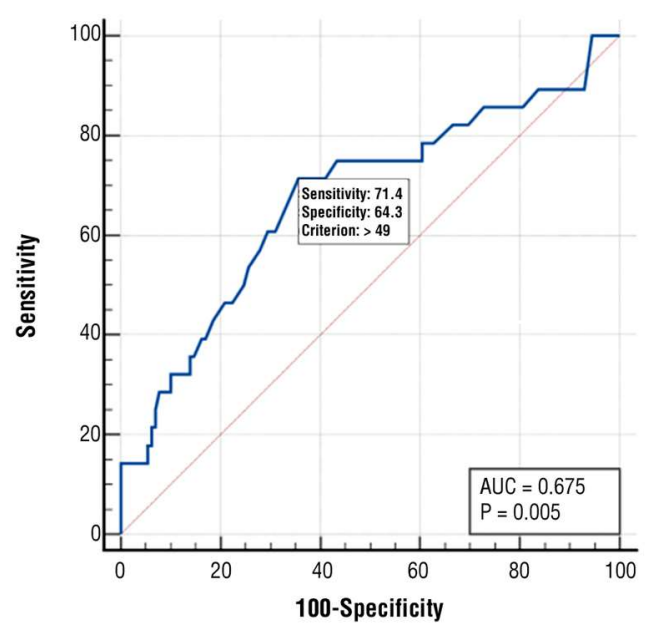

Figure 2. The ROC curve for age and mortality

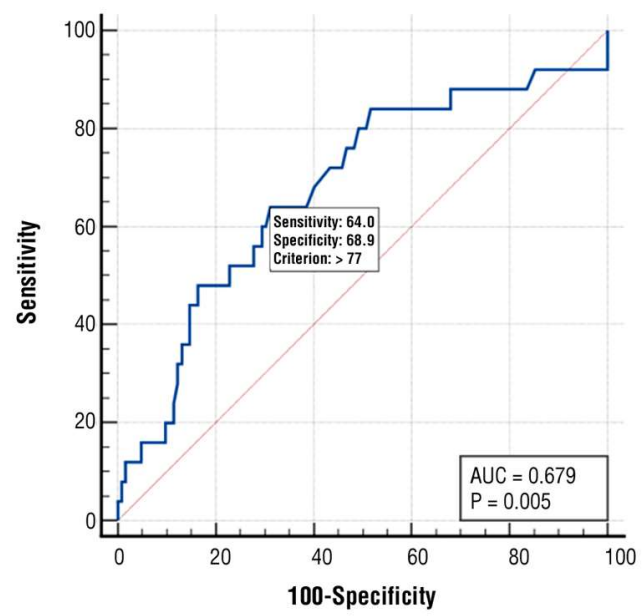

Figure 4. The ROC curve for ALT and mortality

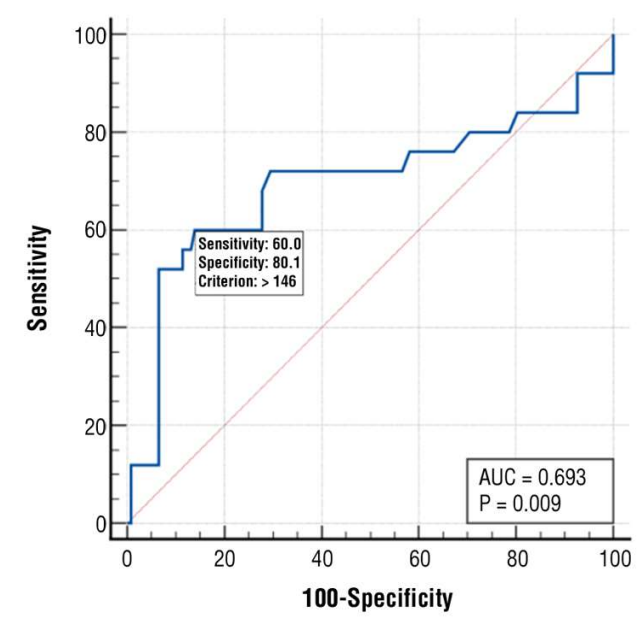

Figure 3. The ROC curve for age and glycemia

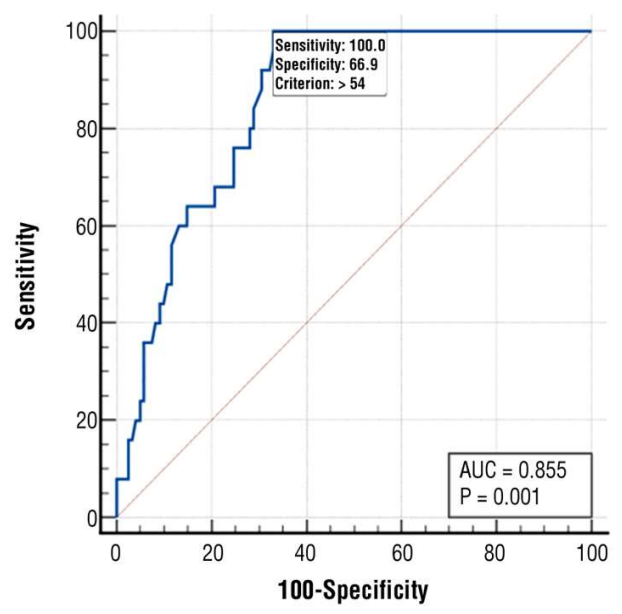

Figure 5. The ROC curve for AST and mortality in the mortality risk with the increase of the score value.

To validate the proposed score, we compared the ISS and NISS values with the score value for the patients included in the research. Thus, a much higher average value of the 2 scores can be observed for the patients who accumulated 5-7 points compared to those who accumulated 1-4 points (Table 5 and Fig. 10, respectively Table 6 and Fig: 11). 


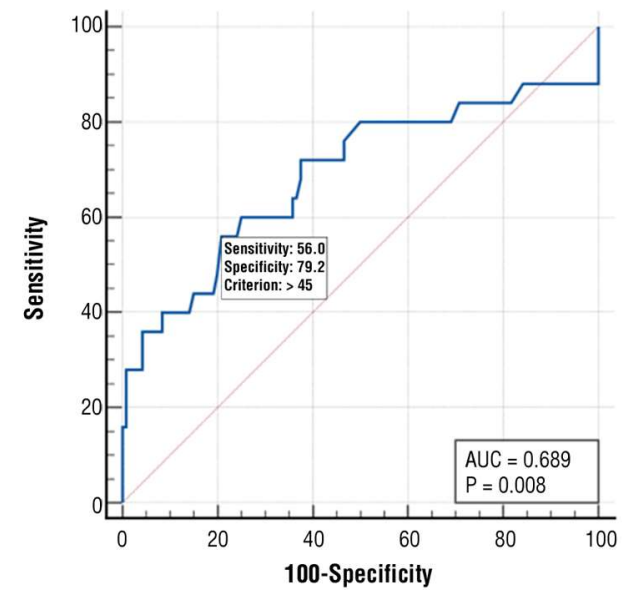

Figure 6. The ROC curve for urea and mortality

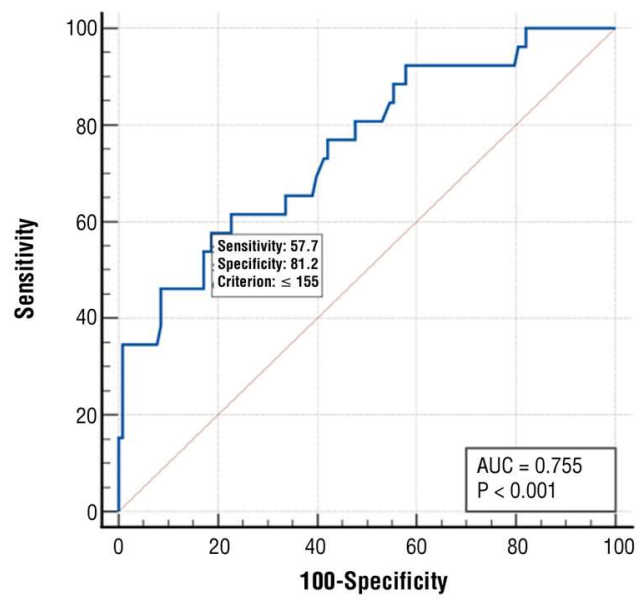

Figure 8. The ROC curve for platelets and mortality

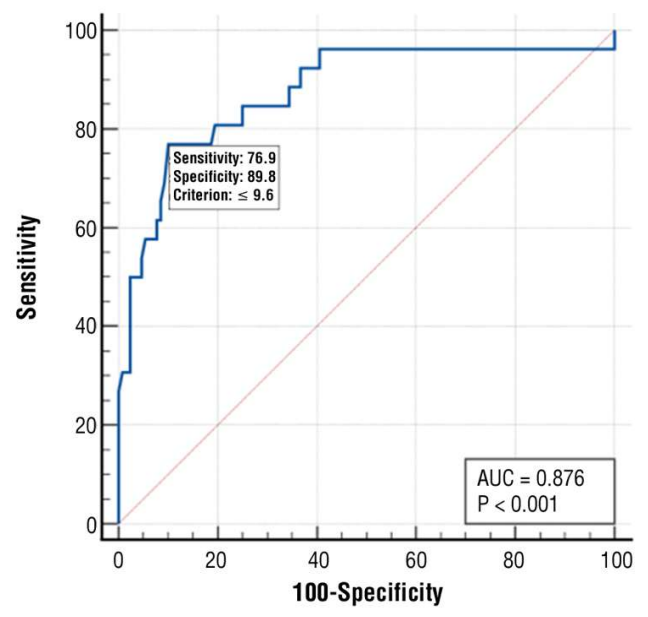

Figure 7. The ROC curve for hemoglobin and mortality

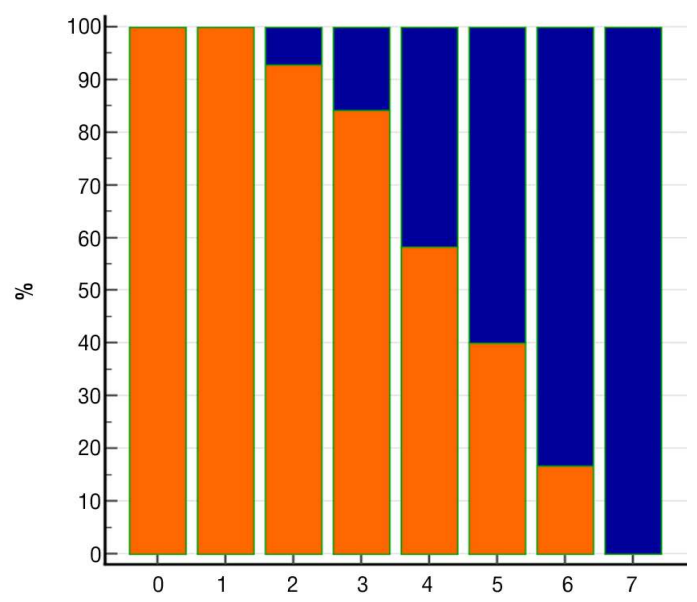

Figure 9. Distribution of cases by score value and mortality

Table 3. Scoring system for mortality risk assessment

\begin{tabular}{lcc}
\hline Points & 0 & 1 \\
\hline Age (years) & $<49$ & $>49$ \\
\hline ALT & $<77$ & $>77$ \\
\hline AST & $<54$ & $>54$ \\
\hline Urea & $<45$ & $>45$ \\
\hline Hemoglobin & $<9.7$ & $>9.7$ \\
\hline Platelets & $<155$ & $>155$ \\
\hline Glucose & $>146$ & $<146$ \\
\hline & &
\end{tabular}

Table 4. Distribution of patients by score value and mortality

\begin{tabular}{lccccccccc}
\hline \multicolumn{1}{c}{ Score Value } \\
\hline Discharge status & 0 & 1 & 2 & 3 & 4 & 5 & 6 & 7 \\
\hline Cured & 24 & 39 & 26 & 16 & 7 & 4 & 1 & 0 \\
\hline Deceased & 0 & 0 & 2 & 3 & 5 & 6 & 5 & 4 & $25(17.6 \%)$ \\
\hline & 24 & 39 & 28 & 19 & 12 & 10 & 6 & 4 & $(82.4 \%)$ \\
& $(16.9 \%)$ & $(27.5 \%)$ & $(19.7 \%)$ & $(13.4 \%)$ & $(8.5 \%)$ & $(7.0 \%)$ & $(4.2 \%)$ & $(2.8 \%)$ & \\
\hline
\end{tabular}


Table 5. Statistics on the ISS value in relation to the proposed risk score value

\begin{tabular}{|c|c|c|c|c|c|c|c|c|}
\hline & ISS & & & & & & & \\
\hline risk score & 0 & 1 & 2 & 3 & 4 & 5 & 6 & 7 \\
\hline $\bar{N}$ & 24 & 39 & 28 & 19 & 12 & 10 & 6 & 4 \\
\hline Minimum & 3.000 & 2.000 & 2.000 & 6.000 & 5.000 & 18.000 & 30.000 & 41.000 \\
\hline Maximum & 66.000 & 51.000 & 54.000 & 66.000 & 75.000 & 75.000 & 75.000 & 75.000 \\
\hline Mean & 21.250 & 25.795 & 25.679 & 31.895 & 39.500 & 38.100 & 53.500 & 59.000 \\
\hline Median & 18.500 & 25.000 & 23.000 & 27.000 & 31.000 & 34.500 & 53.500 & 60.000 \\
\hline$\overline{S D}$ & 13.0292 & 13.3578 & 15.4466 & 18.7169 & 23.5584 & 15.3148 & 16.1586 & 18.5472 \\
\hline
\end{tabular}

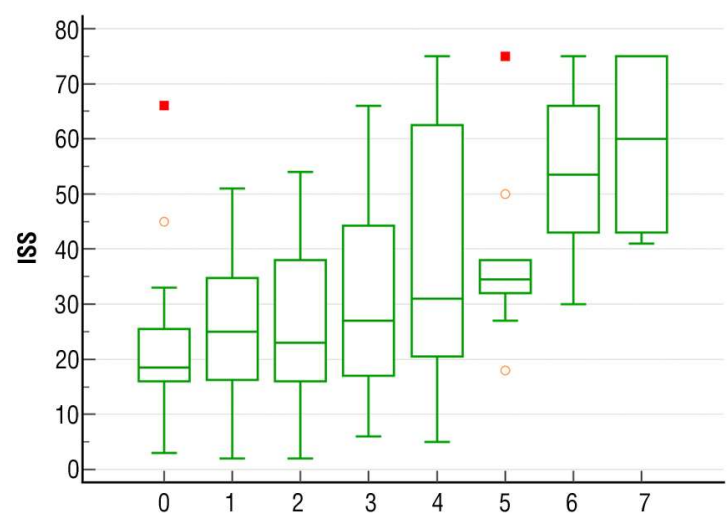

Figure 10. Statistics on the ISS value in relation to the proposed risk score value

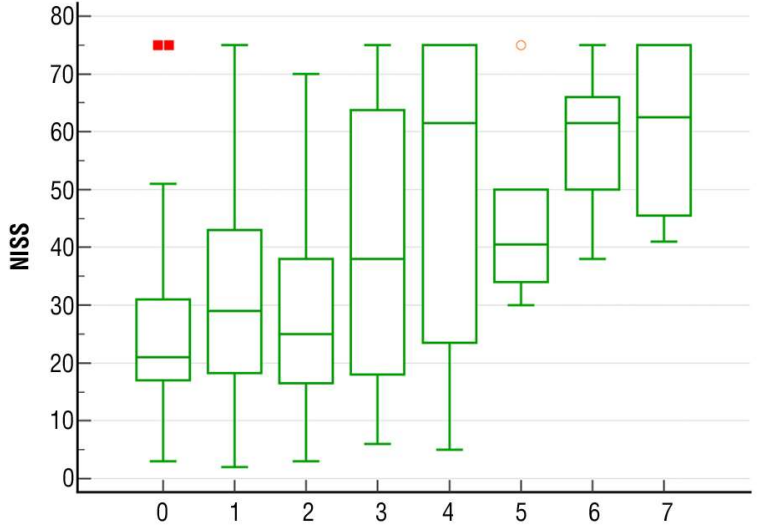

Figure 11. Statistics on the NISS value in relation to the proposed risk score value

Table 6. Statistics on the NISS value in relation to the proposed risk score value

\begin{tabular}{|c|c|c|c|c|c|c|c|c|}
\hline & NISS & & & & & & & \\
\hline risk score & 0 & 1 & 2 & 3 & 4 & 5 & 6 & 7 \\
\hline $\mathrm{N}$ & 24 & 39 & 28 & 19 & 12 & 10 & 6 & 4 \\
\hline Minimum & 3.000 & 2.000 & 3.000 & 6.000 & 5.000 & 30.000 & 38.000 & 41.000 \\
\hline Maximum & 75.000 & 75.000 & 70.000 & 75.000 & 75.000 & 75.000 & 75.000 & 75.000 \\
\hline Mean & 26.125 & 31.744 & 29.179 & 40.526 & 50.583 & 44.000 & 58.667 & 60.250 \\
\hline Median & 21.000 & 29.000 & 25.000 & 38.000 & 61.500 & 40.500 & 61.500 & 62.500 \\
\hline$\overline{S D}$ & 18.5175 & 17.5510 & 19.6658 & 24.5207 & 26.3282 & 13.2077 & 13.2615 & 17.4236 \\
\hline
\end{tabular}

The achieved ROC curve using as parameters the proposed risk score value and mortality highlights a good predictive power of mortality with an AUC of 0.930 ( $\mathrm{p}<0.001)$ (Fig. 12).

\section{Discussions}

Patients with major abdominal traumata require a rapid evaluation, a documentation of the lesions as accurately as possible and a rapid and precise therapeutic response. There are multiple variables that are quantified by the traumatic scores, each with its own advantages and disadvantages.

The CT examination with or without contrast medium remains still the most effective method for diagnosing intra-abdominal lesions, but is associated with high cost, patient irradiation and high time consumption. One of the major shortcomings of this method is the patient with hemodynamic instability $(1,13,14)$, as well as the patients with evolutionary lesions in two stages, many of these lesions being underestimated in the immediate post-traumatic period. 


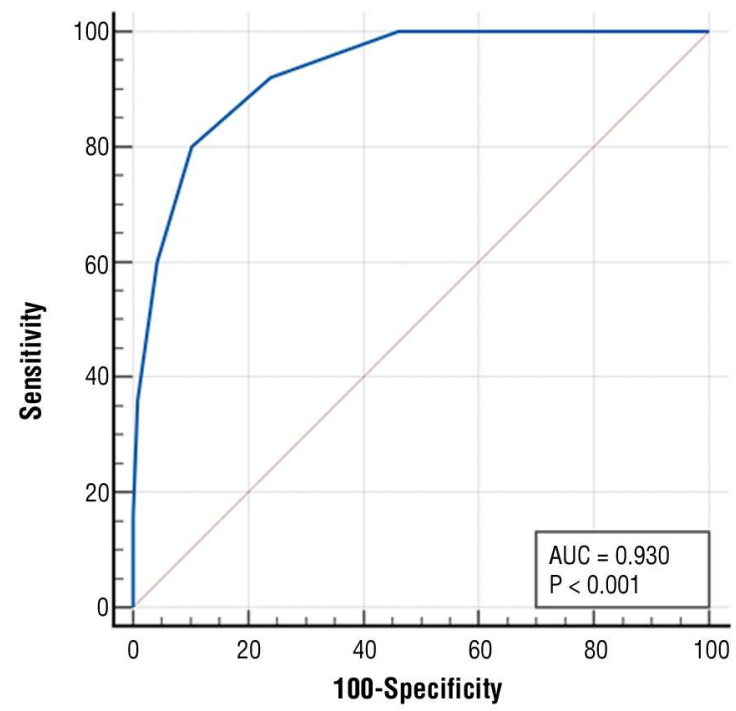

Figure 12. The ROC curve for score value and mortality

The traumatic scores (AIS, ISS, NISS) are valuable tools in terms of the general assessment of injury severity in the polytraumatized patients. They are employed in patients with multisystemic impairment and are based on the assessment of the lesion severity from the injured region / system (AIS).

ISS is calculated as the sum of the squares of the highest AIS scores for the three most severely injured regions and correlates better with mortality and complications than AIS $(1,16)$. Since its introduction in 1974 , it has been one of the most used trauma scores.

In 1997 Osler et al. proposed the modification of the ISS and the use of the NISS, which represented the sum of the squares of the AIS values calculated for the most severely injured organs of the body regardless of the injured region (9).

There are minimal differences between the two scoring systems in predicting the overall mortality, but the NISS is much more accurate in assessing mortality in patients with severe trauma (ISS > 25) (17).

None of these scores manages to focus on the impact on the functionality of the diseased areas / organs. The presence of the severe abdominal trauma may be better suspected and classified by correlating the biochemical constants.
Anemia caused by abdominal trauma, with a decrease in the hematocrit (Hct) level below $36 \%$ seems to show a significant correlation with the CT detection of abdominal trauma (1).

Determining the level of hemoglobin and Hct, without correlating with other imaging or clinical factors, however, shows poor sensitivity and accuracy; their role being to sensitize the clinician to the possibility of the existence of an intra-abdominal injury.

Hemorrhage is one of the important factors associated with abdominal trauma, being one of the major causes of death. Its importance can be revealed by determining the value of hemoglobin and/or hematocrit. A drastic decrease in these constants is an indicator of severe bleeding. Although "artifacted" by volume resuscitation and compensatory mechanisms that act in the hypovolemic shock, the level of hematocrit and hemoglobin is a predictor. Its serial determination, at time intervals, may be a better predictive factor. Thus, the decrease in hemoglobin is associated with tissue hypoperfusion, generalized hypoxia and the appearance of acute post-traumatic coagulopathy, important factors in the evolution of the patient with abdominal trauma (18). Zehtabchi et al. suggest that a decrease of more than 5 units in the value of Hct observed in the first 4 hours after trauma, or by 6.5 in the first quarter of an hour is an indicator for the presence of severe trauma (19). Our study showed a close correlation between the hemoglobin value and mortality at cut-off values of $9.7 \mathrm{~g} / \mathrm{dl}$.

The coagulogram analysis by determining the INR, the prothrombin time, the thromboplastin partial time, the platelet count, the thrombin time, and the fibrinogen levels may provide important information on the occurrence of acute post-traumatic coagulopathy (APTC) (20). Although there is no general consensus in defining it, it is present in approximately $20-30 \%$ of patients with severe trauma and is associated with an increased risk of developing multiple organ failure and death $(20,21)$. An INR value above 1.5 appears 
to have a sufficiently strong clinical significance and correlates with the ISS, the presence of shock and metabolic acidosis (20). Our study did not detect a statistically significant association.

The decrease in platelet count, at a value below $155000 / \mathrm{mm}^{3}$ showed a statistically significant association with mortality $(\mathrm{p}<0.001$, $\mathrm{AUC}=0.755$, sensitivity $=81.2 \%)$. APTC is a major and multifactorially determined dysfunction. The decreased platelet volume is determined by platelet consumption. This seems to be determined by the release of tissue mediators from the traumatized tissues that increase the production of thrombin with a role in the mobilization of platelets, leukocytes and activation of fibrinolysis (22). Platelet count monitoring is also important in anemic syndrome correction therapy by administering blood derivatives to prevent dilutional coagulopathy and post-transfusion thrombocytopenia $(22,23)$. Platelet dysfunction by platelet depletion syndrome in APTC makes the platelet volume useful for the prognosis of the trauma patient (24).

The liver transaminases (ALT, AST) compared in patients with abdominal trauma, but hemodynamically stable, were significantly increased in those with intrabdominal lesions, even if they did not exhibit liver damage (1). Caraduban et al. proposed as a screening method the dosing of ALT, AST associated with the clinical examination in children with blunt abdominal trauma (25). The association of the liver injury in abdominal trauma is positively correlated with the increased ALT and AST serum level (1).

The study by Tann et al. suggests that the normal levels of ALT, AST and LDH may rule out severe liver damage, and the association between high AST and ALT levels with leukocytosis may be used as a screening method in the abdominal trauma involving the liver (1, 26). However, the increase in the hepatic transaminases may also be caused by abdominal trauma involving the kidney, pancreas or spleen, as well as the association of the thoracic trauma affecting the heart and lung. Although this association is close and has also been observed in our study, the low sensitivity does not allow the singular use of this parameter as a predictive factor for the severity of the abdominal trauma (1).

As a result of the abdominal trauma, there is a change in the glucose metabolism, several studies showing a directly proportional relationship between the degree of disturbance and the traumatic score (ISS, AIS) $(4,27)$. Thus, a glycemia above $140 \mathrm{mg} \%$ proved to be a predictor of mortality in polytraumatized patients with a sensitivity of $89 \%$ and a specificity of $49 \%$ (4). Other studies consider that a blood glucose level above 200 $\mathrm{mg}$ is an independent predictor for both the presence of the infection and mortality $(27,28)$. Moreover, the inability to correct the blood glucose levels after hospital admission, below $150 \mathrm{mg} \%$ is a predictor of mortality and morbidity, these patients exhibiting a higher incidence of positive blood cultures and increased mortality $(27,28)$. The current study strengthens this statistically significant correlation between the blood glucose levels and the value of the traumatic score.

The increase in serum urea level, with statistical significance, is most likely due to prerenal renal failure caused by the hypovolemic and traumatic shock. In addition to the phenomenon of centralization of circulation, other factors such as: destruction of the abdominal parietal musculature, or of the interstitial one through direct injury or ischemia, can induce renal hypoperfusion.

The association of the biochemical markers, as predictive factors to the imaging evaluation (FAST ultrasound, CT) fails to have a statistical significance. However, the biochemical constants may have a complementary role in completing and clarifying the anatomically described lesion picture and have an increased value in assessing the possibility of intraabdominal lesions in patients who cannot undergo CT exploration.

The obtained results allowed the achievement of a biochemical score that counts 7 parameters that proved to have a statistically significant importance for mortality (age, ALT, AST, hemoglobin, urea, glycemia, thrombo- 
cythemia). The score proved to have a good predictive value for mortality which correlates with ISS and NISS. The constants used to calculate the proposed score are usually employed in the paraclinical investigations of the emergency department, can be easily tracked in dynamics and do not require special equipment.

The limitations of the study are given by the relatively small and heterogeneous group of patients that determine moderate statistical significance for some of the variables, requiring further studies to validate the conclusions of this score.

\section{Conclusions}

Although with insufficient sensitivity, the biochemical parameters provide important information regarding the diagnosis of patients with abdominal trauma.

The dosage value of AST, ALT, glycemia, hematocrit and hemoglobin may warrant a sufficiently accurate follow-up, especially of patients who are treated conservatively, as they can prove their value in detecting the existence of occult or two-stage lesions.

With good specificity, some of them (AST, ALT, glycemia, INR), may exclude or suggest the possibility of intra-abdominal lesions or capture the occurrence of complications.

A quantification of these biochemical markers performed on prospective studies and on larger cohorts, correlated with the trauma severity scores and imaging scores might prove useful in a finer assessment of the evolutionary possibility of the patients with severe abdominal trauma.

\section{Conflict of Interest}

The authors declare no conflicts of interests.

\section{Ethical Statement}

The study complied with all the ethical standards, namely Law 206/2004 on good conduct in scientific research, technological development and innovation and the Declaration of Helsinki.

\section{Reference}

1. Musalar E, Ersel M, Akarca FK, Kıyan GS, Can O. The predictive value of biochemical parameters in evaluating patients with abdominal trauma: The new scoring system. Turk J Emerg Med. 2017;17(2):48-55

2. Meisler R, Thomsen AB, Theilade P, Abildstrom H, Borge P, Treschow M, et al. Age-related differences in mechanism, cause, and location of trauma deaths. Minerva Anestesiol. 2011; 77(6):592-7.

3. Crawford R, Kruger D, Moeng M. Shock index as a prognosticator for emergent surgical intervention and mortality in trauma patients in Johannesburg: A retrospective cohort study. Ann Med Surg (Lond). 2021;69:102710.

4. Saad S, Mohamed N, Moghazy A, Ellabban G, El-Kamash S. Venous glucose, serum lactate and base deficit as biochemical predictors of mortality in patients with polytrauma. Ulus Travma Acil Cerrahi Derg. 2016; 22(1):29-33.

5. Aziz et al. Frequency and Pattern of Intra-Abdominal Injuries in Patients with Blunt Abdominal Trauma J Trauma Treat 2014, 3.3 DOI: 10.4172/21671222.1000196

6. Ntundu SH, Herman AM, Kishe A, Babu H, Jahanpour OF, Msuya D, et al. Patterns and outcomes of patients with abdominal trauma on operative management from northern Tanzania: a prospective single centre observational study. BMC Surg. 2019;19(1):69.

7. Mnguni MN, Muckart DJJ, Madiba TE. Abdominal trauma in durban, South Africa: factors influencing outcome. Int Surg. 2012;97(2):161-8.

8. Leonher KRL et al Blunt and penetrating abdominal trauma with injury to intra-abdominal organs Rev Latinoam Cir 2013;3(1):20-24

9. Stevenson, Segui-Gomez, Lescohier, Di Scala C, McDonald-Smith G. An overview of the injury severity score and the new injury severity score. Inj Prev. 2001:7(1):10-3.

10. Jansen JO, Yule SR, Loudon MA. Investigation of blunt abdominal trauma. BMJ. 2008:336(7650):938-942.

11. Schroeppel TJ, Croce MA. Diagnosis and management of blunt abdominal solid organ injury. Curr Opin Crit Care. 2007;13(4):399-404.

12. Hoff WS, Holevar M, Nagy KK, Patterson L, Young JS, Arrillaga A, et al. Practice management guidelines for the evaluation of blunt abdominal trauma: the East practice management guidelines work group. J Trauma. 2002:53(3):602-15

13. Tan KK, Bang SL, Vijayan A, Chiu MT. Hepatic enzymes have a role in the diagnosis of hepatic injury after blunt abdominal trauma. Injury. 2009;40(9): 978-983.

14. Karaduman D, Sarioglu-Buke A, Kilic I, Gurses E. The role of elevated liver transaminase levels in children with blunt abdominal trauma. Injury. 2003; 34(4):249-252

15. Tatar Gl, Yilmaz KB, Ergun O, Sener Balas 2, Melih Akıncı 2, Riza Deryol 2, et al. The effect of clinical, laboratory and radiologic results on treatment decision and surgical results in patients admitted to the emergency department with blunt abdominal trauma due to traffic accident. Ulus Travma Acil Cerrahi Derg. 2015:21(4):256-60. Turkish

16. Bilello JF, Davis JW, Lemaster D, Townsend RN, Parks SN, Sue LP, et al. Prehospital hypotension in blunt trauma: identifying the "crump factor". J Trauma. 2011;70(5):1038-42.

17. Li H, Ma YF. New injury severity score (NISS) outperforms injury severity score (ISS) in the evaluation of severe blunt trauma patients. Chin J Traumatol. 2021;24(5):261-265.

18. Spahn DR, Bouillon B, Cerny V, Duranteau J, Filipescu D, Hunt BJ, et al. The European guideline on management of major bleeding and coagulopathy following trauma: fifth edition. Crit Care. 2019;23(1):98.

19. Mosaddegh R, Ashayeri N, Rezai M, Masoumi G, Vaziri S, Mohammadi F, et al Are serial hematocrit measurements sensitive enough to predict intra-abdominal injuries in blunt abdominal trama? Open Access Emerg Med. 2019;11:9-13.

20. Peltan ID, Vande Vusse LK, Maier RV, Watkins TR An INR-based definition of acute traumatic coagulopathy is associated with mortality, venous 
thromboembolism, and multiple organ failure after injury, Crit Care Med. 2015;43(7):1429-38.

21. Niles SE, McLaughlin DF, Perkins JG, Wade CE, Li Y, Spinella PC, Holcomb $\mathrm{JB}$ Increased mortality associated with the early coagulopathy of trauma in combat casualties J Trauma 2008;64(6):1459-63.

22. Ishikura $\mathrm{H}$, KitamuraT. Trauma-induced coagulopathy and critical bleeding: the role of plasma and platelet transfusion. J Intensive Care. 2017;5(1):2.

23. Murphy $\mathrm{CH}$, Hess JR. Massive transfusion red blood cell to plasma and platelet unit ratios for resuscitation of massive hemorrhage. Curr Opin Hematol. 2015;22:533-9.

24. Wohlauer MV, Moore EE, Thomas S, Sauaia A, Evans E, Harr J, et al. Early platelet dysfunction: an unrecognized role in the acute coagulopathy of trauma. J Am Coll Surg. 2012;214(5):739-46.
25. Coleman JJ, Zarzaur BL. Surgical management of abdominal trauma hollow viscus injury. Surg Clin North Am. 2017;97(5):1107-1117.

26. Lee WC, Kuo LC, Cheng YC, Chen CW, Lin YK, Lin TY, et al. Combination of white blood cell count with liver enzymes in the diagnosis of blunt liver laceration. Am J Emerg Med. 2010;28(9):1024-9.

27. Sammour T, Kahokehr A, Caldwell S, Hill AG. Venous glucose and arterial lactate as biochemical predictors of mortality in clinically severely injured trauma patients - a comparison with ISS and TRISS. Injury. 2009; 40(1): 104-8.

28. Vogelzang M, Nijboer JMM, van der Horst ICC, Zijlstra F, ten Duis HJ, Nijsten MW N. Hyperglycemia has a stronger relation with outcome in trauma patients than in other critically ill patients. J Trauma. 2006;60(4): 873-7; discussion 878-9. 